\title{
Potential of Species of Green Coverage in Entisol
}

\author{
Nubia M. Ferreira ${ }^{1}$, Djail Santos ${ }^{2}$, Antonio M. P. Bertino ${ }^{3}$, Alian C. P. Cavalcante ${ }^{4}$, Walter E. Pereira ${ }^{2}$, \\ Antonio M. P. Bertino ${ }^{5} \&$ Ademar P. Oliveira ${ }^{2}$ \\ ${ }^{1}$ Postgraduate Program in Plant Science, Rural Federal University of Semi Arid, Rio Grande do Norte, Brazil \\ ${ }^{2}$ Postgraduate Program in Agronomy, Federal University of Paraíba, Paraiba, Brazil \\ ${ }^{3}$ Postgraduate Program in Plant Production (Agronomy), State University Paulista "Júlio de Mesquita Filho", \\ São Paulo, Brazil \\ ${ }^{4}$ Postgraduate Program in Plant Science, Federal University of Viçosa, Minas Gerais, Brazil \\ ${ }^{5}$ Caraúbas, Rio Grande do Norte, Brazil
}

Correspondence: Nubia M. Ferreira, Postgraduate Program in Plant Science, Rural Federal University of Semi Arid, Municipality of Mossoró, Rio Grande do Norte, Brazil. Tel: 55-849-9857-5141. E-mail: nubiamarisa1@hotmail.com

Received: February 24, $2019 \quad$ Accepted: May 8, $2019 \quad$ Online Published: July 31, 2019
doi:10.5539/jas.v11n11p263
URL: https://doi.org/10.5539/jas.v11n11p263

\begin{abstract}
The intensive use of the soil, associated with the application of chemical fertilizers, contribute to degradation processes that affect soil quality and crop production. The use of techniques that contribute to soil conservation and reduction of external inputsis important for the success of the agriculture, and hedging is an alternative. The objective of this study was to evaluate the phytomass production nutrient accumulation and contents, as well as rate of decomposition of different species used as cover plants. The experimental design was randomized blocks, with nine treatments distributed in three blocks. The treatments were: Canavalia ensiformes (L.) DC., Crotalaria spectabilis Roth, Crotalaria ochroleuca G. Don., Crotalaria juncea L., Dolichos lablab L., Stizolobium niveum (Roxb.) Kuntze, Stizolobium aterrimum Piper \& Tracy, Neonotonia wightii (Wight \& Arn.) J.A. Lackey and Pennisetum glaucum (L.) R.Br. The most recommended species as cover plants are C. ochroleuca and C. spectabilis for they produce more dry matter on the tops, 5.89 and $4.04 \mathrm{~kg} \mathrm{ha}^{-1}$, in addition to greater accumulation of nutrients. C. ochroleuca and C. spectabilis had higher accumulation of $\mathrm{N}, \mathrm{P}, \mathrm{K}, \mathrm{Mg}$ and $\mathrm{S}$, and soil coverage with those species can be a good source of green manure. The recommended species for the highest coverage rate are: $N$. wightii; $S$. niveum and $S$. aterrimum. The recommended species for the lowest rate of decomposition are: $S$. aterrimum; S. niveum; P. glaucum and C. ochroleuca $\left(0.245 ; 0.260 ; 0.264\right.$ and $0.276 \%$ month $\left.^{-1}\right)$.
\end{abstract}

Keywords: decomposition, phytomass, graminea, legumes, macronutrients

\section{Introduction}

The Brazilian Northeast region is characterized by its climatic variability, which, alongside the reduced vegetation coverage, favors the erosive process, reducing the physical, chemical and biological quality of the soil. The use of cover crops has become an efficient practice in keeping the soil covered for longer, as well as promoting the improvement of chemical and physical properties, in addition to keep the soil protected against rainfall impacts. The decomposition and mineralization of this material improves soil fertility, reducing the amount of fertilizers, mainly nitrogen fertilizers, used in crops of economic value (Foloni, Catuchi, Barbosa, Calonego, \& Tiritan 2016; Ordóñez-Fernández, Torres, Márquez-García, Moreno-García, \& Cabonell-Bojollo, 2018).

Knowing the importance of cover crops in the rotation or succession of cropsin semi-arid regions, is essential for the intensive use of the soil, high temperature, low precipitation and high evaporation, cover plants can be an important allied to reduce these factors. In the northeastern region of Brazil, there are already studies with cover plants, however it is necessary to know more about the contribution of phytomass, accumulation of nutrients and decomposition of the material. Among the factors that may contribute to the successful use of these plants are the cycle, climatic conditions and morphological characteristics. 
The cycle of the species is an important aspect to be considered, since a shorter cycle will favor the species to be inserted in the system of rotation and succession of cultures, as well as species that have a fast growth, covering the ground throroughly, which contributes to reduce the incidence of spontaneous plants and protecting the soil from sun exposure (Teodoro, Oliveira, Silva, Fávero, \& Quaresma, 2011). This technique also directly contributes to the accumulation of dry matter and the nutrient supply (i.e., nitrogen) more gradually in the soil (Santos, Nunes, Giongo, Barros, \& Figueiredo, 2018).

The present study allows to determine the effect of biomass, nutrient extraction, decomposition, mineralization and nutrient release on the soil (Ambrosano et al., 2013). The non-replenishment or slow mineralization of the plant material will provide low nutrient availability in the soil, resulting in low nutrient contents in the plant material (Barbosa, Lazarini, Picoli, \& Ferrari, 2011), while higher levels and phytomass production will result in greater accumulations of nutrients, in addition to maintaining soil moisture and reducing erosion.

Given this, the objectiveof this study was to evaluate the phytomass production, nutrient accumulations and contents and rate of decomposition of different species used as cover plants.

\section{Material and Methods}

The experiment was conducted from May to November 2015 in the experimental field of the Olericulture Module, located at the Experimental Farm of Olho D'Água, Areia-PB, belonging to the Federal University of Paraíba (UFPB). The climate of the region is Tropical wet (As, with dry summer), according to Köppen (Alvares et al., 2013).
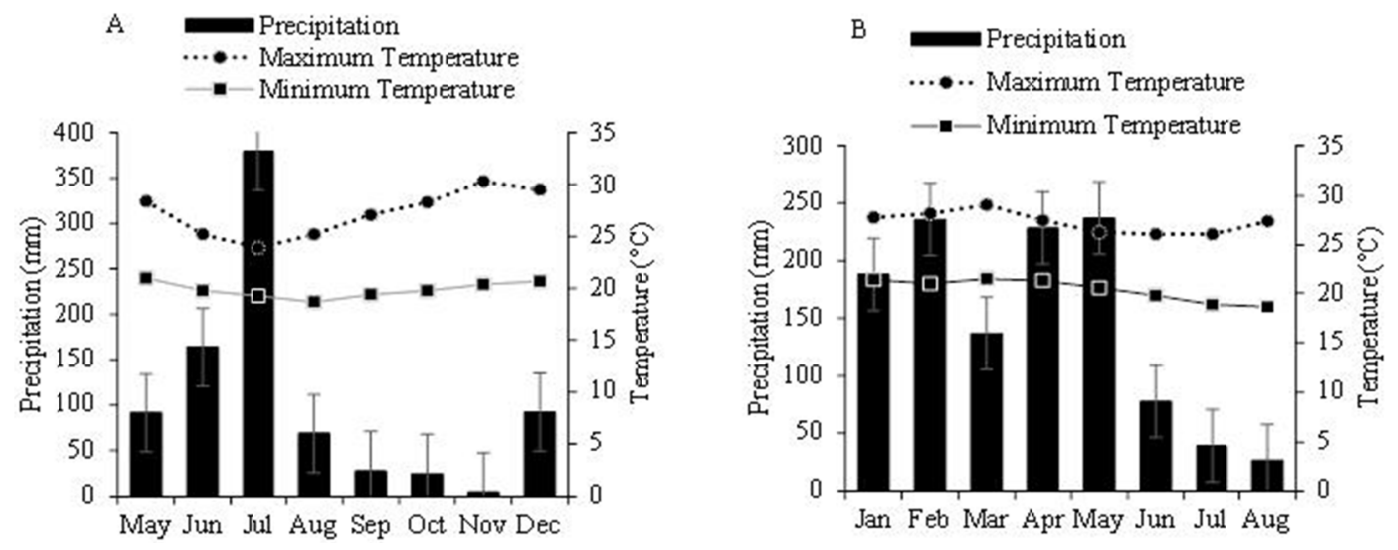

Figure 1. Precipitation, maximum and minimum temperature data for the years 2015 (A) and 2016 (B). Meteorological Station of CCA-UFPB-Areia-PB

The soil was a sandy Entisol (Soil Taxonomy, 2014), with the following properties in layers 0-10 and 10-20 cm: $\mathrm{pH}$ in water, 5.8 and 5.6; calcium, magnesium, potential acidity $\left(\mathrm{H}^{+}+\mathrm{Al}^{3+}\right), 1.91$ and $1.94 ; 0.77$ and $0.75 ; 3.06$ and $3.26 \mathrm{cmolc} \mathrm{dm}^{-3}$, respectively; sodium phosphorus and potassium, 0.03 and $0.03 ; 34.99$ and $37.01 ; 102.30$ and $78.27 \mathrm{mg} \mathrm{dm}^{-3}$ in that order; organic matter, 10.97 and $10.72 \mathrm{~g} \mathrm{~kg}^{-1}$.

The experiment will be conducted in the long term. The initial experiment was carried out in 2014, and 2015 was the second year of cultivation. The experimental design was in randomized blocks, with nine treatments and three replications. The treatments consisted of the following species: (Canavalia ensiformes (L.) DC.), (Crotalaria spectabilis Roth), (Crotalaria ochroleuca G. Don.), (Crotalaria juncea L.), (Dolichos lablab L.), (Stizolobium niveum (Roxb.) Kuntze), (Stizolobium aterrimum Piper \& Tracy), (Neonotonia wightii (Wight \& Arn.) J.A. Lackey) and (Pennisetum glaucum L.) R.Br. For the species $N$. wightii, it was chosen to work with regrowth. In the first year of cultivation, the plot with the species $C$. juncea was lost, being again inserted in the work in the year 2015, being the first year of cultivation while other species were in the second year.

Each plot consisted of a useful area of $24 \mathrm{~m}^{2}(6 \times 4 \mathrm{~m})$, with 8 rows spaced $0.50 \mathrm{~m}$ between rows and $0.10 \mathrm{~m}$ between plants. Spacing between blocks $1.0 \mathrm{~m}$ and between plots $0.50 \mathrm{~m}$. Seeding was performed considering a depth of $3 \mathrm{~cm}$. The experiment was conducted in rainfed cultivation and the cultural treatments were carried out during initial period.

The soil cover rate was evaluated for the species $S$. niveum, S. aterrimum, C. ensiformes, $N$. wightii and $D$. lablab at 30; 45; 60; 75 and 90 DAS by the number method of intersections described by (Alvarenga, Costa, Moura Filho, 
\& Regazzi, 1995). The green phytomass was obtained when the plots were with $50 \%$ of the flowering plants, and a square of wood of $0.50 \times 0.50 \mathrm{~m}$ was randomly released at 4 points of the plot. The material inside the square was collected and weighed. Based on the data, the dry weight of shoot, roots and total $\left(\mathrm{t} \mathrm{ha}^{-1}\right)$ was calculated.

After weighing the samples, they were sent to the laboratory, where they were washed and conditioned in a forced circulation oven at $65^{\circ} \mathrm{C}$ for 72 hours. After drying, the material was weighed, ground and sent to the laboratory to determine macronutrient contents (Brazilian Agricultural Research Company [EMBRAPA], 1998). The accumulation of nutrients was obtained through product of the amount of dry mass by the content of the nutrients of the species.

After cutting the plants in the flowering period, material was collected to analyze the rate of dry matter decomposition. The material was dried in a forced circulation oven at $65^{\circ} \mathrm{C}$ until constant weight. The carbon in the material was determined by the muffle method (Goldin, 1987). Based on the $\mathrm{C}$ and $\mathrm{N}$ contents, the $\mathrm{C} / \mathrm{N}$ ratio of the samples was determined (Table 1). Then, $30.0 \mathrm{~g}$ (corresponding to the material of each treatment) were separated and packed in nylon bags (litter bags), measuring $0.04 \mathrm{~m}^{2}$, made with a $1 \mathrm{~mm}$ mesh screen (Alves, Souto, Souto, \& Holanda, 2006). Subsequently, five bags were distributed per treatment on the soil surface in each plot, totaling 135 bags in the experimental area.

The dry matter decomposed as a function of time was calculated by the difference between the initial weight ( 30.0 g) and the weight after oven drying at $65^{\circ} \mathrm{C}$, thus obtaining the remaining dry weight percentage. With these data, decomposition rates were estimated by several regression models commonly used in decomposition studies. The model that provided the best fit for all species was the first-order exponential: $\mathrm{Mt}=\mathrm{M}_{0} \cdot \mathrm{e}^{-\mathrm{kt}}$ (Barlocher et al., 2005), in which: Mt is the dry weight percentage remaining after $t$ days and $\mathrm{M}_{0}$ is $100 \%$ when $t$ is equal to zero. Thus, for each cover plant, in each experimental plot, an equation was obtained. The half-life $\left(t_{1} / 2=0.693 / k\right)$ was calculated. Based on the adjusted model, the graphs were generated in the $\mathrm{R}^{\circledR}$ program, according to the calculation to determine the half-life $\left(T_{1 / 2}\right)$ proposed by Paul and Clark (1989), where, $t_{1 / 2}=0.693 / k$, being $t_{1 / 2}$ the time required for $50 \%$ decomposition and constant decomposition.

Data were submitted to analysis of variance and, when significant, the Tukey test $(\mathrm{p} \leq 0.05)$ was performed using the $\mathrm{SAS}^{\circledR}$ statistical package (Cody, 2015).

\section{Results and Discussion}

In Figure 2A, the soil cover data of the species fitting the quadratic polynomial model are presented. At 90 DAS, S. niveum presented $100 \%$ coverage area, while $S$. aterrimum at 90 DAS covered $90.95 \%$ of the area. Greater soil coverage was attributed to the species with prostrate/climbing habit, S. niveum, S. aterrimum and D. lablab-100; 90.95 and $87.50 \%$, respectively.

In figure $2 \mathrm{~B}$, the coverage rate data for $N$. wightii is presented. At $30 \mathrm{DAS}, N$. wightii presented $50 \%$ coverage, indicating its capacity for spontaneous suppression, since it has high competitiveness and fast coverage of soil. At 60 DAS, it reached $100 \%$ coverage. Mucunas and C. ensiformes are efficient in terms of greater soil coverage and suppression of weeds. Species with low growth habit have greater ability to smother and aggressivity, reducing the population of spontaneous plant species.
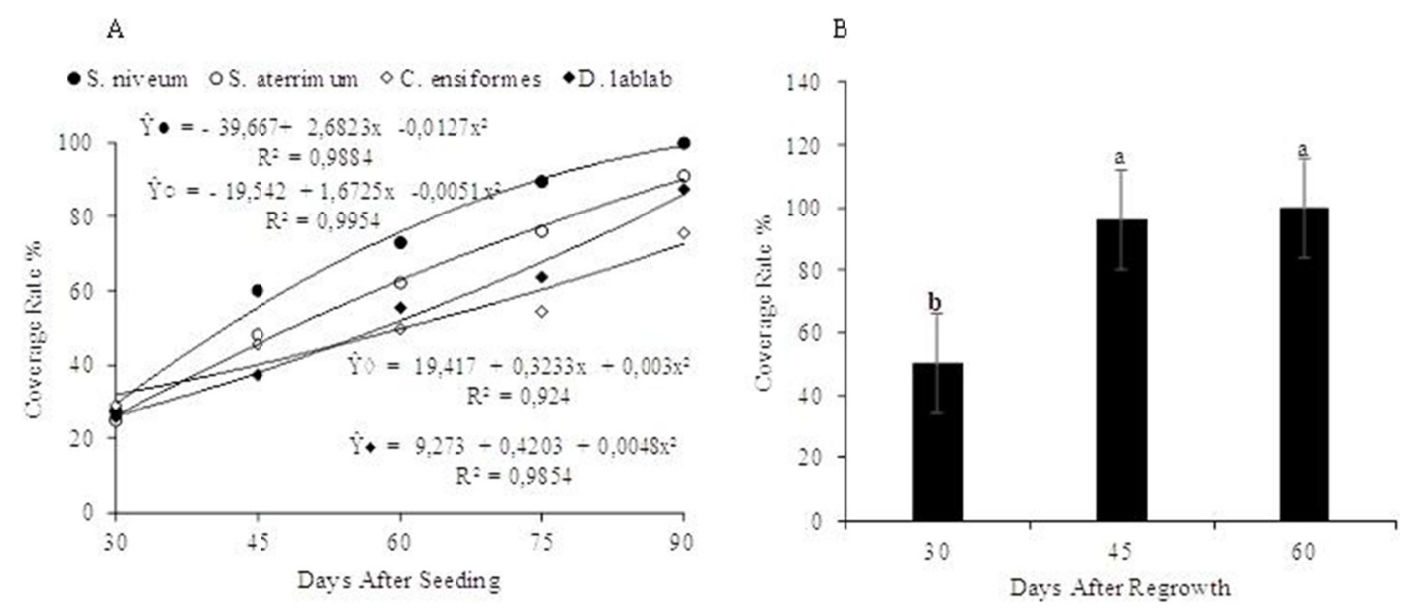

Figura 2. Rate of cover of species used as green manure S. niveum, S. aterrimum, C. ensiformes, D. lablab, at 30, 45, 60, 75 and 90 DAS (Figura 2A) N. wightii at 30, 45 and 60 DAR (Figura 2B) 
During the conduction of the experiment, rainfall was irregular, delaying species' development; coverage rates were lower than those described by (Souza, Santos, Rios, \& Souza, 2018). C. ochroleuca produced the highest amount of dry matter of tops $5.89 \mathrm{t} \mathrm{ha}^{-1}$ (Figure 3A). C. spectabilis produced $4.04 \mathrm{t} \mathrm{ha}^{-1}$ of dry mass, having the second highestproduction. The species $N$. wightii and C. juncea produced 3.12 and $2.98 \mathrm{tha}^{-1}$, respectively.

The higher dry matter production of the area cultivated with $C$. spectabilis and C. ochroleuca can be explained by the fact that these species present a more woody stem when compared to the others that have more tender stems. The rainfed cultivation and the irregular rains in the region during the period (Figure 1A) may have contributed to a reduction in the mass production of the dry matter of the species $S$. niveum, S. aterrimum, C. ensiformes, N. wightii, D. lablab. According to Pacheco et al. (2011), among the factors that interfere in phytomass production are late sowing and low rainfall.
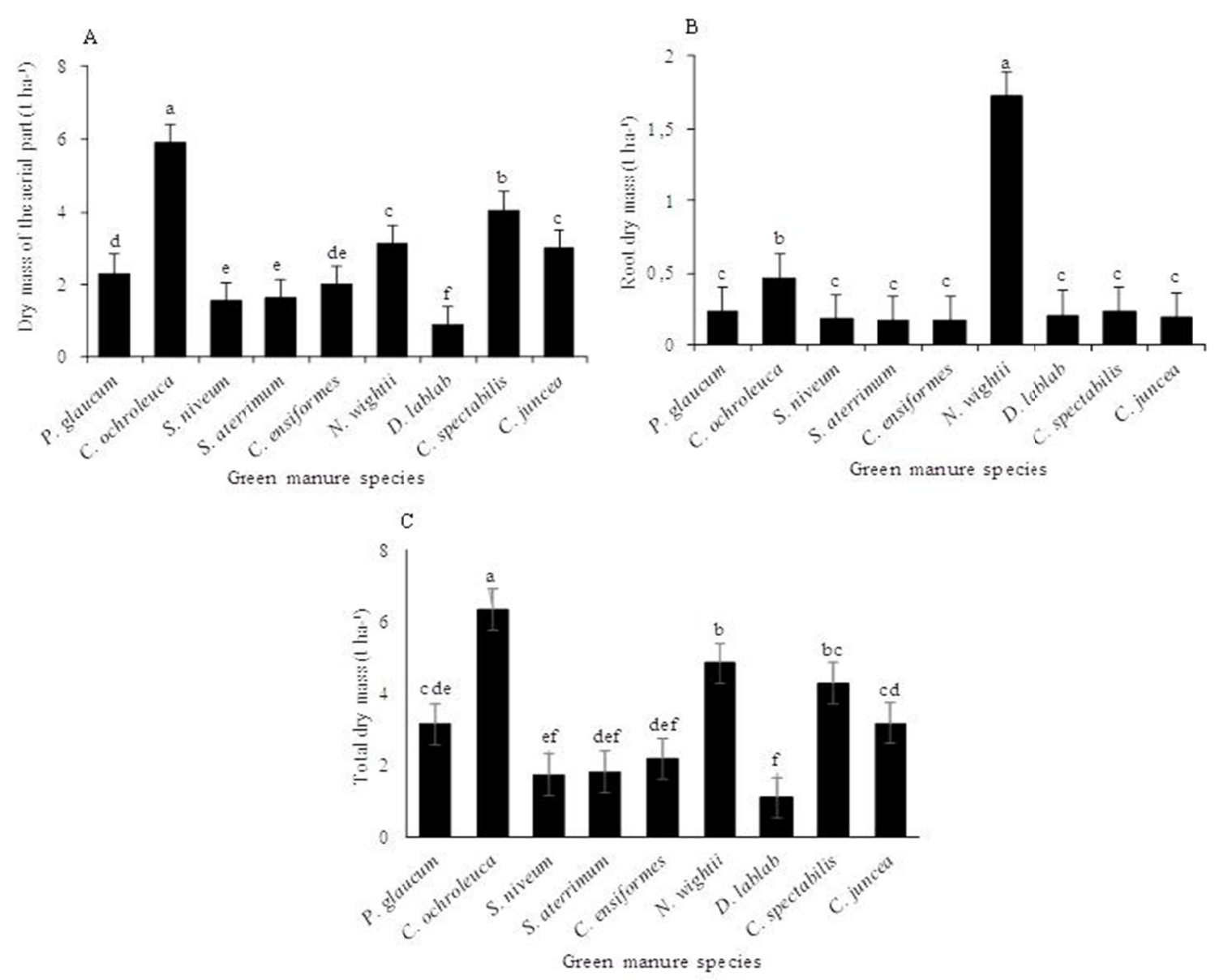

Figure 3. Mean mass values of dry matter of aerial (A) root (B) and total (C) of species used for green fertilization, in the stage which $50 \%$ of the plants were blooming. Means followed by the same letters do not differ by Tukey's test $(\mathrm{p} \leq 0.05)$

Greater root dry mass (Figure 3B) was obtained for N. wightii, $1.73 \mathrm{t} \mathrm{ha}^{-1}$, which has deep roots and high productivity, possibly associated with regrowth cultivation. C. ochroleuca presented the second highest value of the dry matter in the root, demonstrating its potential for the mass production of the roots and consequent increase of organic matter in the soil throughout its cultivation. The other species presented similar values, due to the similar characteristics of pivotal roots.

For the variable total dry matter (Figure 3C), the C. ochroleuca species produced the highest mass $\left(6.35 \mathrm{t} \mathrm{ha}^{-1}\right)$, differing from the others, which can be explained by satisfactory yield in both shoot and root, followed by $N$. wightii $\left(4.85 \mathrm{t} \mathrm{ha}^{-1}\right)$ and C. spectabilis $\left(4.28 \mathrm{t} \mathrm{ha}^{-1}\right)$. Higher productivity may be associated with higher plant density per linear meter; in addition, productivity values may be influenced by planting season and climate, which may inhibit or stimulate vegetative development of the species. 
(Macedo, Costa, Viana, \& Freire, 2013) found out yield of C. juncea and P. glaucum (3.80 to 3.0 t ha $^{-1}$ ) were similar to this study $\left(3.17\right.$ and $\left.3.13 \mathrm{t} \mathrm{ha}^{-1}\right)$. The species $C$. ensiformes and $C$. spectabilis had nitrogen contents of 30.86 and $30.15 \mathrm{~g} \mathrm{~kg}^{-1}$ (Figure 4A), similar to the species C. ochroleuca, S. niveum, N. wightii and D. lablab $\left(24.75,24.68,27.74\right.$ and $24.92 \mathrm{~g} \mathrm{~kg}^{-1}$, respectively). The species $P$. glaucum presented lower content (12.39 $\mathrm{g}$ $\left.\mathrm{kg}^{-1}\right)$.
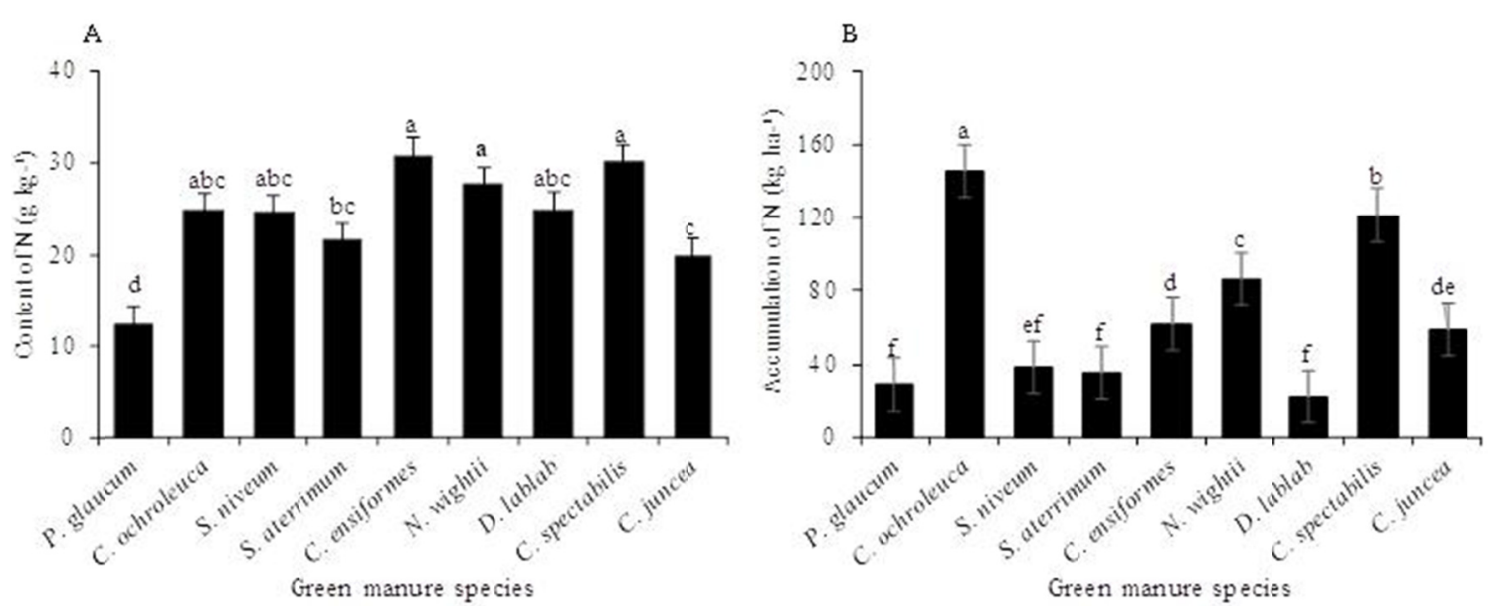

Figure 4. Average nitrogen content (A) and accumulation (B) in the dry matter of green manure, in the stage which $50 \%$ of the plants were flowering. Means followed by the same letters do not differ by

Tukey test $(\mathrm{p} \leq 0.05)$

C. ochroleuca accumulated $145.93 \mathrm{~kg} \mathrm{ha}^{-1}$ of $\mathrm{N}$, differing from the other species (Figure 4B), while $C$. spectabilis accumulated the second largest N content. Santos et al. (2018) explains that cover crops, especially legumes, provide greater availability and maintenance of stable concentrations of nitrogen and carbon in the soil.

The legumes have a greater capacity of fixing the atmospheric $\mathrm{N}$ through the symbiosis performed with bacteria of the genus Rhizobium, and the $\mathrm{N}$ fixed by the legumes is immobilized in the plant material. After the cutting of the species, with the process of decomposition and mineralization of the material $\mathrm{N}$ will be released to the soil, attending the crop in succession (Ordóñez-Fernández et al., 2018). Leguminosae presented higher levels of $\mathrm{N}$ (except $C$. juncea), which can be explained by the fact that this was the first year of cultivation of this species in the experimental area, and there were no residues from the previous crop, provoking a lower content of this nutrient when compared to other legume species in the second year of cultivation.

P. glaucum had the highest P content, followed by C. ensiformes and C. spectabilis $\left(4.63 ; 3.08\right.$ and $2.77 \mathrm{~g} \mathrm{~kg}^{-1}$, respectively) (Figure 5A). With respect to the accumulation of $\mathrm{P}$ (Figure 5B), the species that accumulated the most were C. ochroleuca, C. spectabilis and P. glaucum $\left(14.19 ; 11.31\right.$ and $10.71 \mathrm{~kg} \mathrm{ha}^{-1}$, respectively). 

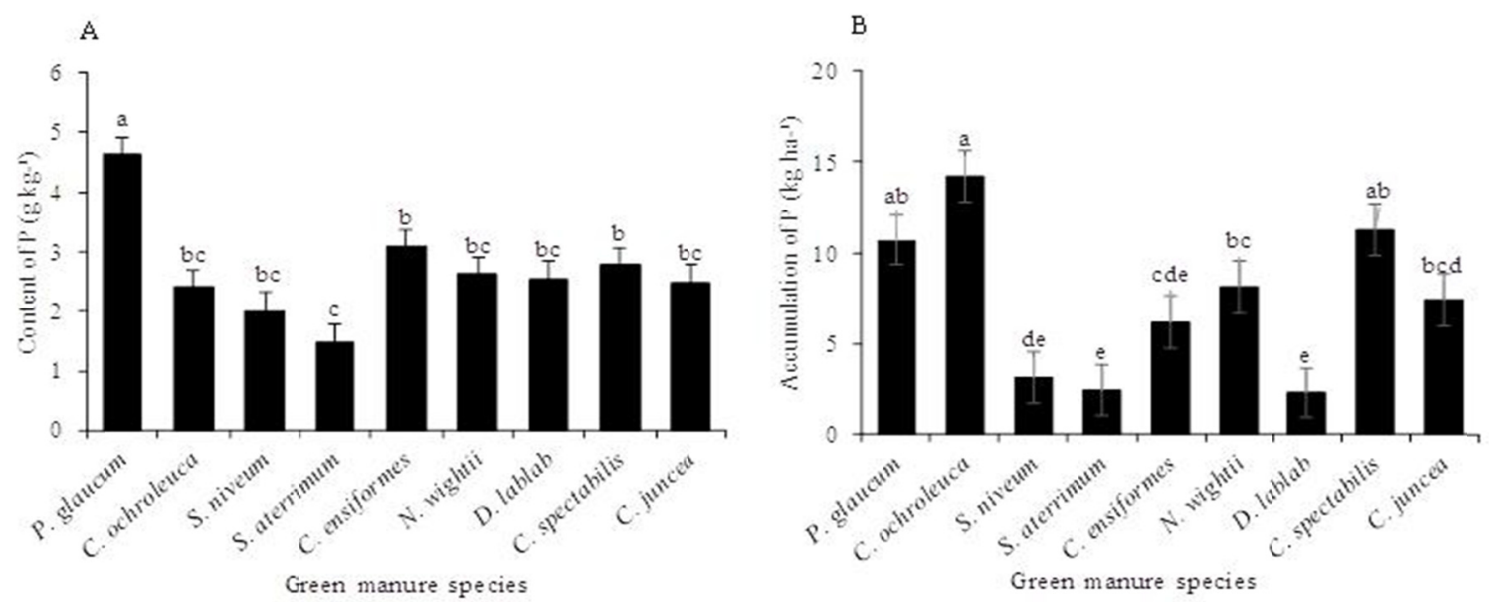

Figure 5. Content (A) and phosphorus accumulation (B) in the dry matter of green manures, in the stage which $50 \%$ of the plants were flowering. Means followed by the same letters do not differ by Tukey test $(\mathrm{p} \leq 0.05)$

Some species presented low dry matter yield, however they presented satisfactory nutrient contents, which grants them the capacity to recycle nutrients. P. glaucum, although presenting low phytomass productivity, presented higher levels and accumulations of $\mathrm{P}$, therefore this species could be considered efficient in recycling this nutrient (Rodrigues et al., 2012).

Boer et al. (2007) state that accumulation of nutrients varies according to species, phenological stage, dry matter production and planting season. In the present study, the climatic conditions during the experiment were irregular, which may have contributed to phytomass productivity and nutrient accumulations to be lower than those found in the literature.

P. glaucum had a $\mathrm{K}$ content of $23.75 \mathrm{~g} \mathrm{~kg}^{-1}$, the highest content when compared to the other species (Figure 6A). C. ochroleuca, $N$. wightii, $C$. spectabilis and $C$. juncea did not differ among themselves, and their values were $16.88 ; 18.75 ; 16.87$ and $16.67 \mathrm{~g} \mathrm{~kg}^{-1}$, respectively. Regarding the accumulation, C. ochroleuca accumulated $99.26 \mathrm{~kg} \mathrm{ha}^{-1}$ of $\mathrm{K}$, being superior to the other species (Figure 6B).
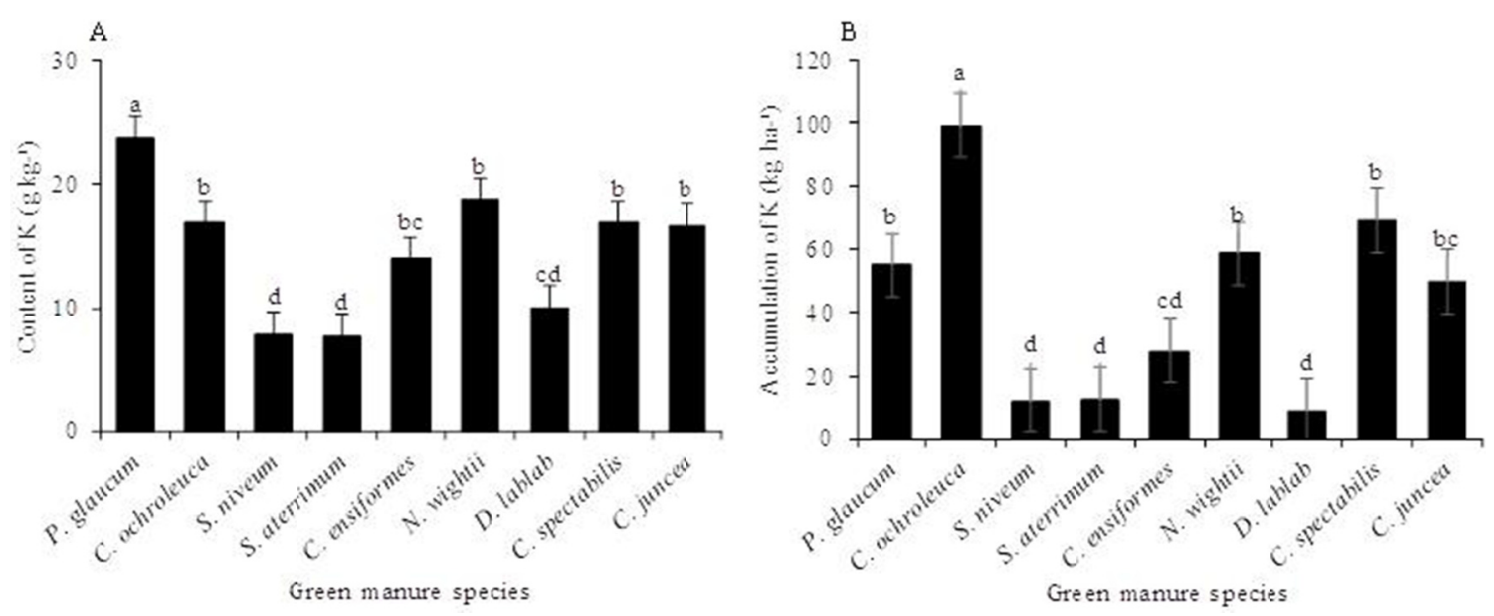

Figure 6. Content (A) and potassium accumulation (B) in the dry matter of green manures, in the stage which $50 \%$ of the plants were flowering. Means followed by the same letters do not differ by Tukey test $(p \leq 0.05)$

Soil type, temperature, humidity, plant density, consortium system, water availability and nutrients affect the production and nutrient uptake in cover crops. Results for the species with lower accumulation of $\mathrm{K}$ are related to lowest phytomass production and lower $\mathrm{K}$ content.

The highest Ca content was found in the plant tissue of $C$. ensiformes $\left(22.07 \mathrm{~g} \mathrm{~kg}^{-1}\right)$, not differing from the species C. spectabilis, S. aterrimum and D. lablab (21.71; 19.20 and $7.78 \mathrm{~g} \mathrm{~kg}^{-1}$, respectively) (Figure 7A). The highest accumulations of $\mathrm{Ca}$ were found in Crotalarias spectabilis and C. ochroleuca $\left(87.38 ; 73.97 \mathrm{~kg} \mathrm{ha}^{-1}\right)$, 
differing from the others (Figure 7B). The results for $C$. juncea were superior to those of Barbosa et al. (2011), which verified accumulation of $\mathrm{Ca}$ of 26.04 and $17.01 \mathrm{~kg} \mathrm{ha}^{-1}$, in two sowing periods.
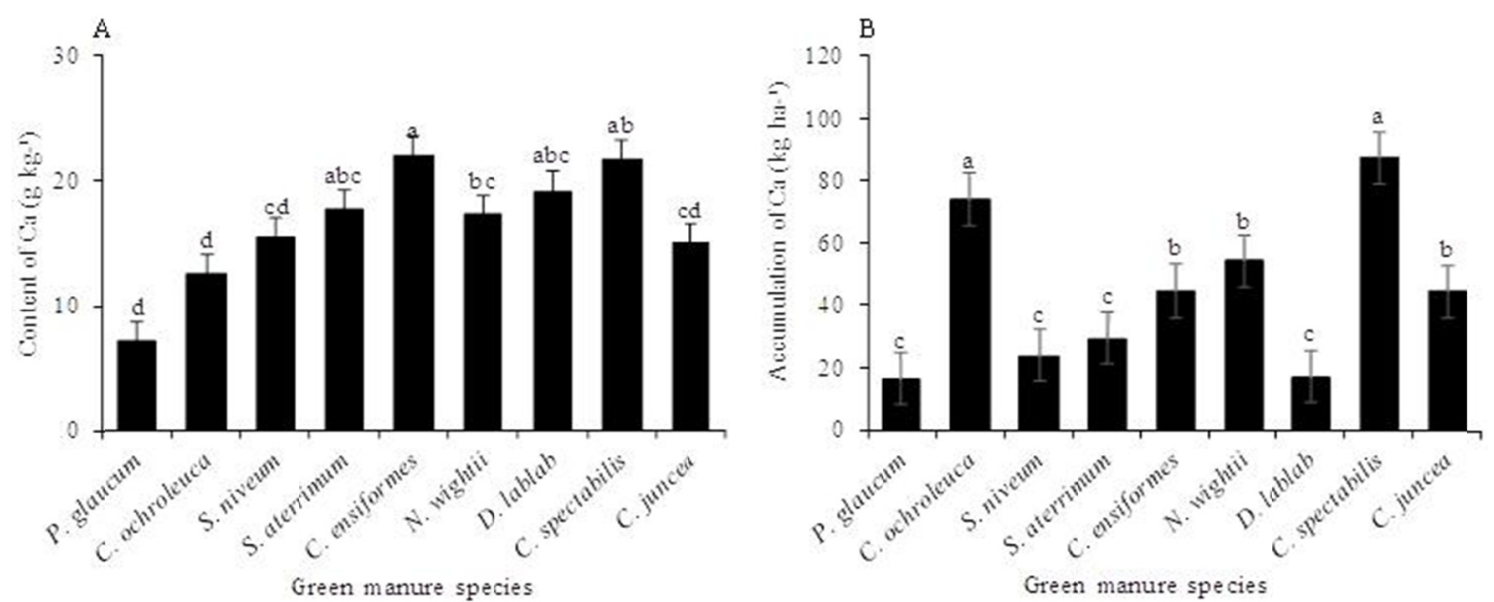

Figure 7. Calcium content (A) and accumulation (B) in the dry matter of green manures, in the stage which 50\% of the plants were flowering. Means followed by the same letters do not differ by Tukey test $(p \leq 0.05)$

$\mathrm{Mg}$ contents are presented in Figure 8A. C. ochroleuca obtained a higher content, followed by $N$. wightii, $C$. juncea and D. lablab $\left(5.14 ; 4.75 ; 4.27\right.$ and $\left.4.06 \mathrm{~g} \mathrm{~kg}^{-1}\right)$. C. ochroleuca had higher accumulation of $\mathrm{Mg}(30.37 \mathrm{~kg}$ $\mathrm{ha}^{-1}$ ) (Figure 8B).

Mg contents were similar to the study by Rodrigues et al. (2012) (Figure 1), for C. juncea, S. aterrimum, C. ensiformes and P. glaucum $\left(4.1 ; 3.0 ; 3.6\right.$ and $\left.4.5 \mathrm{~g} \mathrm{~kg}^{-1}\right)$. In order to increase nutrient accumulation, fertile soil and available nutrients are essential, in addition to adequate precipitation, for higher phytomass production (Pacheco et al., 2011).
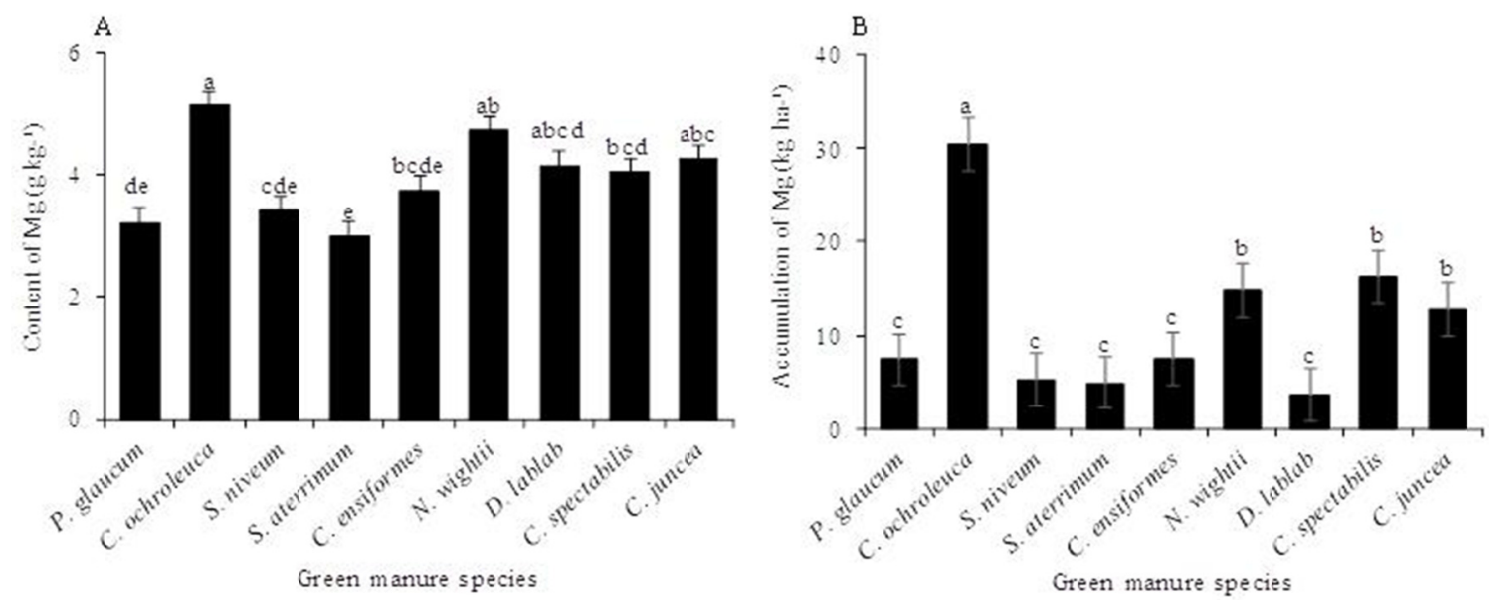

Figure 8. Content (A) and magnesium accumulation (B) in the dry matter of green manures, in the stage which $50 \%$ of the plants were flowering. Means followed by the same letters do not differ by Tukey test $(\mathrm{p} \leq 0.05)$

P. glaucum had higher S content, $2.04 \mathrm{~g} \mathrm{~kg}^{-1}$ (Figure 9A). For accumulation of S, C. ochroleuca was superior, but similar to $C$. spectabilis, P. glaucum and $N$. wightii, with $6.45 ; 5.49 ; 4.72$ and $4.53 \mathrm{~kg} \mathrm{ha}^{-1}$, respectively (Figure 9B). S content observed for P. glaucum in this study was similar to the one observed by Foloni et al. (2016), $2.56 \mathrm{~g} \mathrm{~kg}^{-1}$, and higher than described by Rodrigues et al. (2012), $1.2 \mathrm{~g} \mathrm{~kg}^{-1}$. 

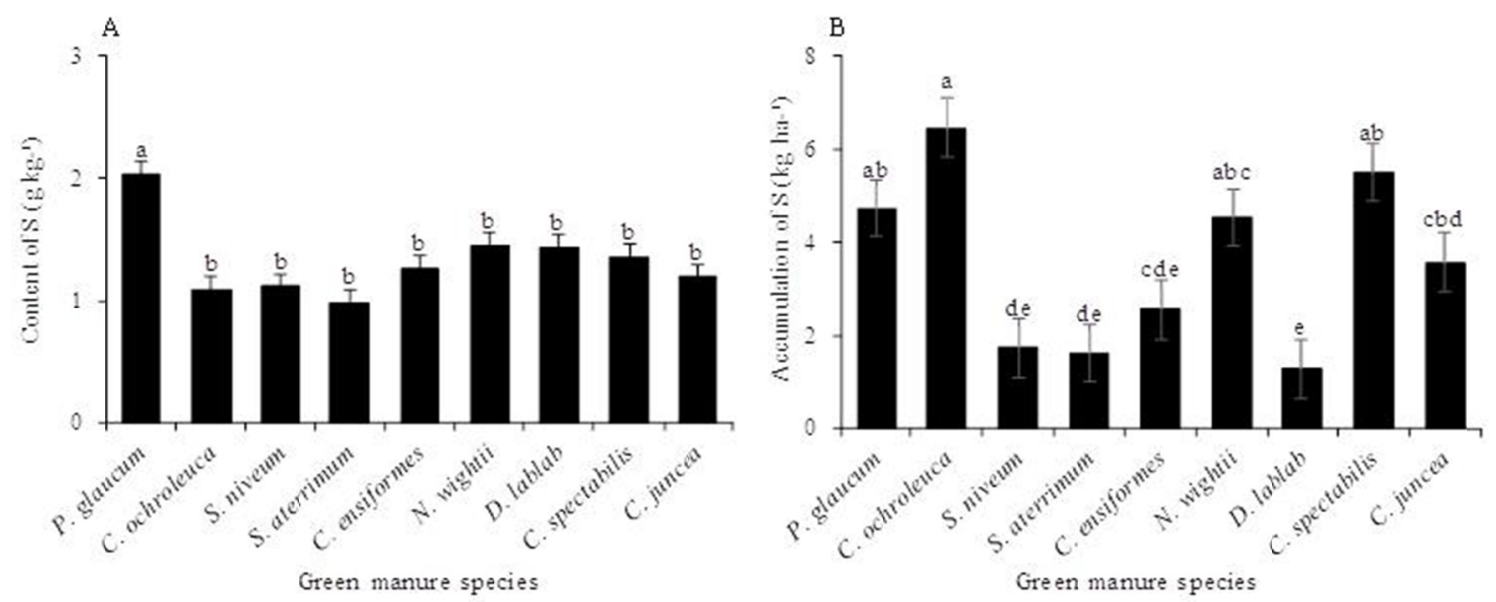

Figure 9. Content (A) and sulfur accumulation (B) in the dry matter of green manures, in the stage which $50 \%$ of the plants were flowering. Means followed by the same letters do not differ by Tukey test $(p \leq 0.05)$

Accumulation of nutrients is proportional to mass production, and in order to obtain significant results it is necessary to choose the species recommended for the region and, mainly, that the climatic conditions favors both its development and greater mass production by area (Pacheco et al., 2011). Coating plants can be efficient in accumulating nutrients in the plants dry matter, which, through chemical decomposition and mineralization, will provide chemical improvement of the soil, thereby reducing the use of fertilizers (Rodrigues et al., 2012).

Table 3 shows the values of $\mathrm{M}_{0}$ (maximum decomposable potential, $\%$ ); $k$ (rate of decomposition, $\%$ month $^{-1}$ ); $\mathrm{R}^{2}$ (coefficient of determination of the model); $\mathrm{T}_{1 / 2}$ (half-life, or time required for $50 \%$ decomposition, months) and the $\mathrm{C} / \mathrm{N}$ ratio of the species.

Table 3. Maximum decomposable potential, monthly decomposition rates, model parameters, number of months to occur $50 \%$ decomposition and $\mathrm{C} / \mathrm{N}$ ratio of coverage plants

\begin{tabular}{llllll}
\hline Species & $\mathrm{M}_{0}$ & $K$ & $\mathrm{R}^{2}$ & $\mathrm{~T}_{\frac{1}{2} \text { months }}$ & C/N Ratio \\
\hline P. glaucum & 100 & 0.264 & 0.97 & 2.62 & 36 \\
C. ochroleuca & 100 & 0.276 & 0.98 & 2.61 & 19 \\
S. niveum & 100 & 0.26 & 0.99 & 2.66 & 19 \\
S. aterrimum & 100 & 0.245 & 0.99 & 2.82 & 22 \\
C. ensiformes & 100 & 0.352 & 0.98 & 1.96 & 15 \\
N. wightii & 100 & 0.299 & 0.99 & 2.31 & 17 \\
D. lablab & 100 & 0.317 & 0.98 & 2.18 & 18 \\
C. spectabilis & 100 & 0.44 & 0.98 & 1.57 & 15 \\
C. juncea & 100 & 0.335 & 0.98 & 2.06 & 23 \\
\hline
\end{tabular}

Decomposition of the plant material depends on factors such as precipitation, temperature, humidity and the presence of organisms in the soil. Figure 10 shows the values and intervals of $k$ with respect to the rate of decomposition of the species. The highest rate of decomposition was observed for C. spectabilis with $k=0.44 \%$ month $^{-1}$, which may be related to its higher $\mathrm{N}$ content and lower $\mathrm{C} / \mathrm{N}$ ratio $(15: 1)$. The decomposition of $P$. glaucum, $C$. ochroleuca, $S$. niveum and $S$. aterrimum was similar with mean monthly decomposition of 0.264 ; $0.276 ; 0.26$ and $0.245 \%$ of month ${ }^{-1}$, differing from C. ensiformes, $N$. wightii, D. lablab and C. juncea (0.352; $0.299 ; 0.317$ and $0.335 \%$ month $^{-1}$ ).

At 30 days, the species presented $25 \%$ of similarity and slower decomposition, which can be explained due to the low rainfall recorded in December (Figure 1A), except for the species C. spectabilis, of which approximately $35 \%$ of the initial material had already been decomposed at 30 days. From the 30 days, the decomposition rate was faster, compared to the other periods, which can be explained by an increase in precipitation recorded from January (Figure 1B). 

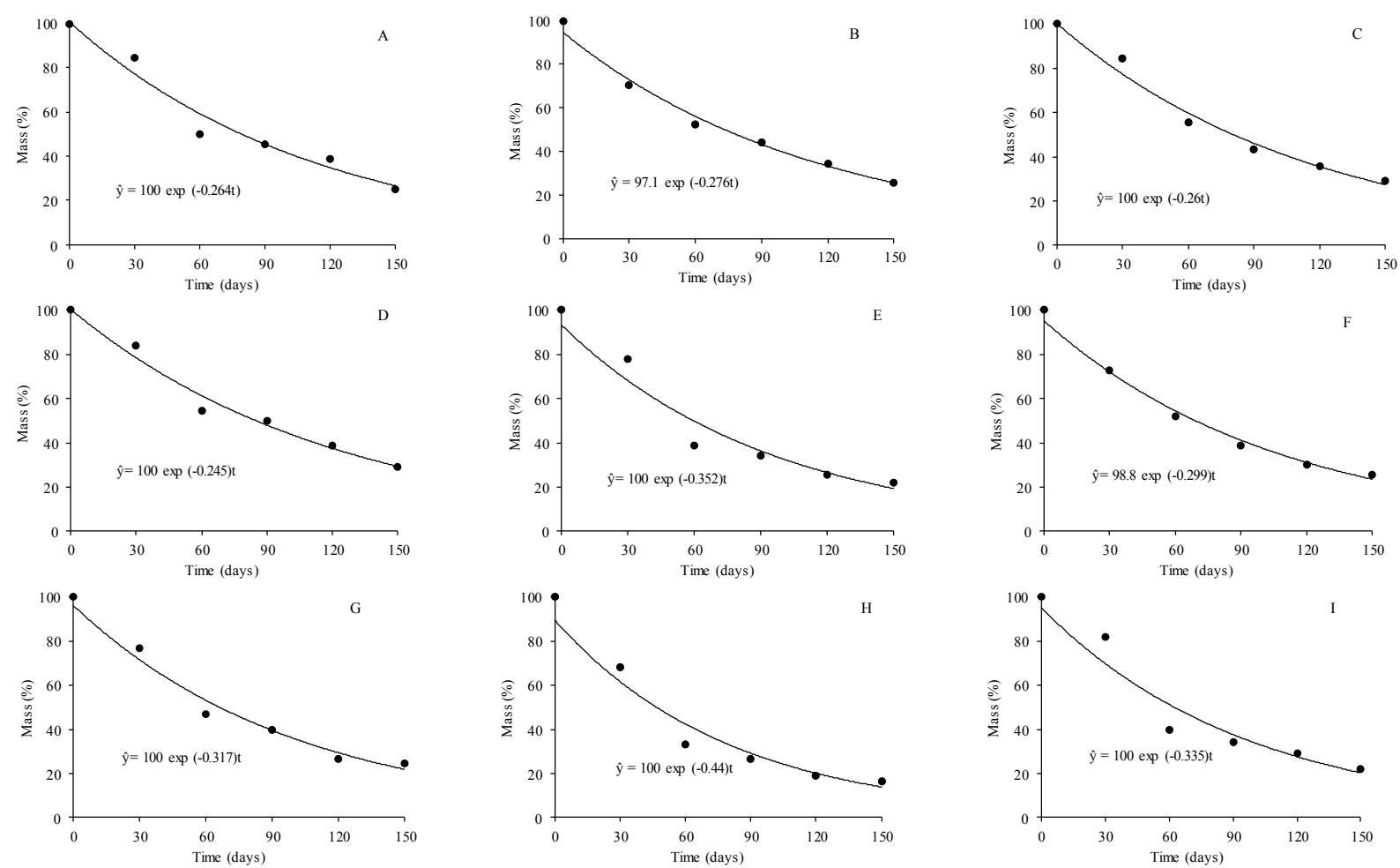

Figure 10. Percentage change of mass as a function of time in green manure species, $P$. glaucum (A.), C. ochroleuca (B.), S. niveum (C.), S. aterrimum (D.), C (E.), N. wightii (F.), D. lablab (G.), C. spectabilis (H.), C. juncea (I.), evaluated at 0, 30, 60, 90, 120 and 150 days

The fact that the species present similarity in the rate of decomposition may be related to the values of the near $\mathrm{C} / \mathrm{N}$ ratio, as well as the half-life time (Boer et al., 2007). The half-life ( $\left.\mathrm{T}_{1 / 2}\right)$, which means the time needed to reach $50 \%$ of the dry matter decomposition of each species, is presented in Table 3 . Species with higher $T_{1 / 2}$ are presumed to be used when the objective is to keep the residues under the soil, and species with a lower $T_{1 / 2}$ when the succession is an agronomic crop, since nutrient decomposition and mineralization is faster (Viola et al., 2013). C. spectabilis presented the lowest $T_{1 / 2}$, and $S$. aterrimum presented higher $T_{1 / 2}$; the highest $T_{1 / 2}$ may be related to high lignin contents, making it difficult for microorganisms to act and, consequently, slowing decomposition (Viola et al., 2013).

The climate is a fundamental factor for the decomposition process, mainly precipitation and temperature, since both influence the environmental conditions of the soil, therefore, in the greater or lesser microbial activity. According to (Santana, Vieira, Souto, Gondim, \& Fonseca, 2011), the type of management interferes with the rate of decomposition, and the incorporation of the material accelerates the decomposition process, as well as precipitation. In the present study, precipitation and temperature were higher from January to May (Figure 1B), during which time the samples were collected.

\section{Conclusions}

The most recommended species to be used as cover plants are: C. ochroleuca and C. spectabilis, since they produce more dry matter on the tops, 5.89 and $4.04 \mathrm{~kg} \mathrm{ha}^{-1}$, and also showed greater accumulation of nutrients.

C. ochroleuca and C. spectabilis had the highest accumulations of $\mathrm{N}, \mathrm{P}, \mathrm{K}, \mathrm{Mg}$ and $\mathrm{S}$, and soil cover may be a good source of green manure.

The species recommended for the highest coverage rate are: $N$. wightii; S. niveum and S. aterrimum.

The species recommended for the lowest rate of decomposition are: S. aterrimum; S. niveum; P. glaucum and C. ochroleuca $\left(0.245 ; 0.260 ; 0.264\right.$ and $\left.0.276 \% \mathrm{month}^{-1}\right)$. 


\section{References}

Alvares, C. A. Stape, J. L., Sentelhas, P. C., Gonçalves, J. L. M., \& Sparovek, G. (2013). Köppen’s climate classification map for Brazil. Meteorologische Zeitschrift, 22, 711-728. https://doi.org/10.1127/0941-2948/ 2013/0507

Alvarenga, R. C., Costa, L. M., Moura Filho, W., \& Regazzi, A. J. (1995). Características de alguns adubos verdes de interesse para a conservação e recuperação de solos. Pesquisa Agropecuária Brasileira, 30, 175-185.

Alves, R., Souto, J. S., Souto, P. C., \& Holanda, A. C. (2006). Aporte e decomposição de serrapilheira em área de Caatinga, na Paraíba, Revista Biologia e Ciência da Terra, 6, 194-203.

Ambrosano, E. J., Cantarella, H., Rossi, F., Schammass, E. A., Silva, E. C., Ambrosano, G. M. B. ... Muraoka, T. (2013). Desempenho de adubos verdes e da primeira soqueira de cana-de-açúcar cultivados consorciadamente. Revista Brasileira de Agroecologia, 8, 80-90.

Barbosa, C. E. M., Lazarini, E., Picoli, P. R. F., \& Ferrari, S. (2011). Determinação da massa seca, teor de nutrientes e cobertura do solo de espécies semeadas no outono-inverno. Revista Brasileira de Ciências Agrárias, 6, 265-272. https://doi.org/10.5039/agraria.v6i2a1136

Barlocher, F. (2005). Leaf mass loss estimated by litterbag technique: A pratical guide In M. A. S. Graça, F. Bärlocher, \& M. Gessner (Eds.), Methods to study litter decomposition (pp. 37-42). The Netherlands: Springer. https://doi.org/10.1007/1-4020-3466-0_6

Boer, C. A., Assis, R. L., Silva, G. P., Braz, A. J. B. P., Barroso, A. L. L., Cargnelutti Filho, A., \& Pires, F. R. (2007). Ciclagem de nutrientes por plantas de cobertura na entressafra em um solo de cerrado. Pesquisa Agropecuária Brasileira, 42, 1269-1276. https://doi.org/10.1590/S0100-204X2007000900008

Cody, R. (2015). An Introduction to $S A S \circledR$ University Edition (1st ed.). SAS Institute Inc., Cary, North Carolina.

EMBRAPA (Empresa Brasileira De Pesquisa Agropecuária). (1998). Análises químicas para avaliação da fertilidade do solo (Métodos Usados na Embrapa Solos) (3rd ed). Brasília, DF.

Foloni, J. S. S., Catuchi, T. A., Barbosa, A. M., Calonego, J. C., \& Tiritan, C. S. (2016). Acúmulo de nutrientes e relação $\mathrm{C} / \mathrm{N}$ em diferentes estádios fenológicos do milheto submetido à adubação nitrogenada. Revista Agroambiente, 10, 1-9. https://doi.org/10.18227/1982-8470ragro.v10i1.2798

Goldin, A. (1987). Reassesing the use of loss-on-ignition for estimating organic matter content in noncalcareous soils. Com. Soil Science and Plant Analysis, 18, 1111-1116. https://doi.org/10.1080/00103628709367886

Macêdo, G. A. R., Costa, E. L., Viana, M. C. M., \& Freire, F. M. (2013). Características produtivas e tecnológicas de variedades de cana-de-açúcar em sucessão a diferentes cultivos em pastagem degradada. Revista Brasileira de Ciências Agrárias, 8, 223-228. https://doi.org/10.5039/agraria.v8i2a2465

Ordóñez-Fernández, R., Torres, M. A. R. R., Márquez-García, J., Moreno-García, M., \& Carbonell-Bojollo, R. M. (2018). Legumes used as cover crops to reduce fertilisation problems improving soil nitrate in an organic orchard. Europ. Journal Agronomy, 95, 1-13. https://doi.org/10.1016/j.eja.2018.02.001

Pacheco, L. P., Leandro, W. M., Machado, P. L. O. A., Assis, R. L., Cobucci, T., Madari, B. E., \& Petter, F. A. (2011). Produção de fitomassa e acúmulo e liberação de nutrientes por plantas de cobertura na safrinha. Pesquisa Agropecuária Brasileira, 46, 17-25. https://doi.org/10.1590/S0100-204X2011000100003

Paul, E., \& Clark, F. (1989). Soil microbiology and biochemistry (p. 275). San Diego: Academic Press. https://doi.org/10.1016/B978-0-12-546805-3.50008-4

Rodrigues, G. B., Sá, M. E., Valério Filho, W. V., Buzetti, S., Bertolin, D. C., \& Pina, T. P. (2012). Matéria e nutrientes da parte aérea de adubos verdes em cultivos exclusivo e consorciado. Revista Ceres, 59, 380-385. https://doi.org/10.1590/S0034-737X2012000300013

Santana, J. A. S., Vieira, F. A., Souto J. S., Gondim, S. C., \& Fonseca, F. C. E. (2011). Decomposição da biomassa foliar de cana-de-açúcar em um Neossolo na região de Areia-PB. Revista Caatinga, 24, 28-32.

Santos, T. L., Nunes, A. B. A., Giongo, V., Barros, V. S., \& Figueiredo, M. C. B. (2018). Cleaner fruit production with green manure: The case of Brazilian melons. Journal of Cleaner Product, 181, 260-270. https://doi.org/10.1016/j.jclepro.2017.12.266

Soil Survey Staff. (2014). Keys to Soil Taxonomy (12th ed.). USDA-Natural Resources Conservation Service, Washington, DC. 
Soares, C. M. J., Rambo, J. R., Cavallari, L. A., Oliveira, M. S., \& Soares, D. M. J. (2015). Produção de adubos verdes no cerrado e seus efeitos sobre as plantas daninhas. Revista Ciência Agroambiental, 13, 57-64.

Souza, G. A. V. S., Souza, T. A. F., Santos, D., Rios, E. S., \& Souza, G. J. L. (2018). Agronomic evaluation of legume cover crops for sustainable agriculture. Russian Agricultural Sciences, 44, 31-38. https://doi.org/ $10.3103 / \mathrm{S} 106836741801009$

Teodoro, R. B., Oliveira, F. L., Silva, D. M. N., Fávero, C., \& Quaresma, M. A. L. (2011). Aspectos agronômicos de leguminosas para adubação verde no cerrado do alto vale do Jequitinhonha. Revista Brasileira de Ciência do Solo, 35, 635-643. https://doi.org/10.1590/S0100-06832011000200032

Viola, R., Benin, G., Cassol, L. C., Pinnow, C., Flores, F. M., \& Bornhofen, E. (2013). Adubação verde e nitrogenada na cultura do trigo em plantio direto. Bragantia, 72, 90-100. https://doi.org/10.1590/ S0006-87052013005000013

\section{Copyrights}

Copyright for this article is retained by the author(s), with first publication rights granted to the journal.

This is an open-access article distributed under the terms and conditions of the Creative Commons Attribution license (http://creativecommons.org/licenses/by/4.0/). 